\title{
The RhoA GTPase-Activating Protein DLC2 Modulates RhoA Activity and Hyperalgesia to Noxious Thermal and Inflammatory Stimuli
}

\author{
Fred K.C. Chan ${ }^{a}$ Stephen S.M. Chung ${ }^{d}$ Irene O. $\mathrm{Ng}^{\mathrm{c}}$ Sookja K. Chunga, b \\ ${ }^{a}$ Department of Anatomy, ${ }^{b}$ Research Center of Heart, Brain, Hormone and Healthy Aging, and ${ }^{\mathrm{c}}$ Department of \\ Pathology, State Key Laboratory for Liver Research, Li Ka Shing Faculty of Medicine, The University of Hong Kong, \\ Hong Kong, SAR, China; ${ }^{\mathrm{d}}$ Division of Science and Technology, United International College, Zhuhai, China
}

\section{Key Words}

Deleted in liver cancer $2 \cdot$ Pain - Nerve conduction velocity · Inflammation $\cdot$ Hyperalgesia $\cdot$ RhoA $\cdot$ ERK

\begin{abstract}
Deleted in liver cancer 2 (DLC2) is a novel Rho GTPase-activating protein that regulates RhoA activity. DLC2 is ubiquitously expressed in most tissues, including the brain, spinal cord and peripheral nerves, and is thought to be involved in actin cytoskeletal reorganization. Unlike DLC1-deficient mice, DLC2-deficient mice ( $\mathrm{DLC2}^{-/-}$) are viable and without gross anatomical abnormalities. Interestingly, $\mathrm{DLC}^{-/-}$mice exhibit hyperalgesia to noxious thermal stimuli and inflammation-inducing chemicals, such as formalin and acetic acid. There was no difference in the structure or morphology of cutaneous or sural nerves between $\mathrm{DLC2}^{+/+}$and $\mathrm{DLC2}^{-/-}$ mice. However, sensory nerve conduction velocity in $\mathrm{DLC2}^{-/-}$mice was significantly higher than that in $\mathrm{DLC2} 2^{+/+}$ mice, whereas motor nerve conduction velocity was not affected. After formalin injection, DLC2 ${ }^{-/-}$mice showed increased RhoA activity in the spinal cord and an increased number of phosphorylated ERK1/2-positive cells. The inflammatory hyperalgesia in $\mathrm{DLC2}^{-/-}$mice appeared to be mediated through the activation of RhoA and ERK1/2. Taken to-
\end{abstract}

gether, DLC2 plays a key role in pain modulation during inflammation by suppressing the activation of RhoA and ERK to prevent an exaggerated pain response, and $\mathrm{DLC}^{-/-}$mice provide a valuable tool for further understanding the regulation of inflammatory pain.

Copyright $\odot 2011$ S. Karger AG, Basel

\section{Introduction}

Deleted in liver cancer 2 (DLC2) is a member of the family of deleted in liver cancer genes; it is also known as steroidogenic acute regulatory protein-related lipid transfer (START) domain-containing protein 13. This gene encodes a protein containing 1,113 amino acids that shares $51 \%$ identity and $65 \%$ similarity with the amino acid sequence of DLC1 [1]. DLC2 has a sterile alpha domain, a START domain and a Rho GTPase-activating protein (RhoGAP) domain. An additional functional domain was identified in residues $322-329$ as an ATP/GTPbinding site [1].

DLC2 was first thought to be a tumor suppressor gene because it is located on chromosome 13q12.3, a region often deleted in hepatocellular carcinoma [2-9]. In addition, DLC2 expression is reduced in $18 \%$ of human he-

\section{KARGER}

Fax +4161306 1234 E-Mail karger@karger.ch www.karger.com

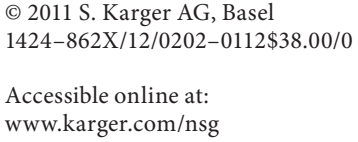

Prof. Sookja K. Chung

Department of Anatomy, 1/F. Laboratory Block, Li Ka Shing Faculty of Medicine

The University of Hong Kong, 21 Sassoon Road

Hong Kong, SAR (China)

Tel. +852 2819 9172, E-Mail skchung@ hkucc.hku.hk 
patocellular carcinoma samples [1]. DLC2 exhibited RhoGAP activity specific for RhoA, which may mediate stress fiber formation $[1,10,11]$. The increased expression of its RhoGAP domain inhibited the proliferation of breast cancer cells [10] and HepG2 cells [11] by inactivating RhoA. In addition, increased expression of its GAP domain inhibited the migration of HepG2 cells $[1,11]$. However, one study showed that DLC2 deficiency did not increase the rate of spontaneous liver tumor formation or diethylnitrosamine-induced hepatocarcinogenesis [12].

Activation of RhoA is involved in the initiation and maintenance of inflammatory and neuropathic pain $[13$, 14]. Intraperitoneal injection of the ROCK inhibitor Y27632 in mice produced an anti-nociceptive effect to noxious thermal stimuli and inflammatory agents, such as formalin and acetic acid $[14,15]$. This was probably because RhoA and ROCK regulate glutamine and/or acetylcholine release from peripheral nerves [16-18]. Thus, the RhoA/ROCK pathway plays a role in neurotransmitter release from sensory nerves. RhoA is also critical for the regulation of actin cytoskeleton formation during many cellular events. The regulation of the cytoskeleton, especially in nervous tissues, is important for neurite outgrowth, axonal targeting and branching. Although DLC2 is thought to regulate RhoA, its role in actin cytoskeletal organization and in the development of nervous tissues and neuropathic pain is not clear.

In this study, we investigated nerve morphology in $\mathrm{DLC}^{-/-}$mice and their response to noxious thermal stimuli and inflammatory chemicals. We found that there was no significant difference in the structure of the cutaneous and sural nerves in DLC2 ${ }^{-/-}$mice compared to $\mathrm{DLC}^{+/+}$mice under normal conditions. In addition, hyperalgesia to heat and inflammation in $\mathrm{DLC} 2^{-/}$mice was associated with increased activity of RhoA and ERK1/2, the signaling molecules involved in hyperalgesia, in the dorsal horn of the spinal cord.

\section{Animals and Methods}

Animals

Male 9-11-week-old wild-type (DLC2 ${ }^{+/+}$) and DLC2-deficient $\left(\mathrm{DLC}^{-/-}\right)$mice were used. DLC2 $2^{-/-}$mice were backcrossed to C57BL/6N for 6 generations. For morphological assessment, $\mathrm{DLC}^{+/+}$and $\mathrm{DLC} 2^{-/-}$mice (N7 backcross to $\mathrm{C} 57 \mathrm{BL} / 6 \mathrm{~N}$ ) were mated with Thyl-YFP mice, which had yellowish-green fluorescent protein (YFP) in the sensory and motor neurons (31). All mice were maintained in a 12/12-hour light/dark cycle with food and water ad libitum. Animal experiments were carried out following the guidelines set forth by the Committee on the Use of Live Animals in Teaching and Research at The University of Hong Kong.
Reverse-Transcription PCR

For semi-quantitative reverse-transcription PCR (RT-PCR) analysis, total RNA was prepared from mouse tissues using TRI reagent. First-strand cDNA was synthesized from $1 \mu \mathrm{g}$ total RNA using SuperScript ${ }^{\mathrm{TM}}$ (Invitrogen) reverse transcriptase. DLC2 mRNA and GAPDH were amplified by the following primers: for the DLC2 gene, the forward primer 5'-TGTGCTGGCAGGGACGGC and the reverse primer 5'-TGCCAATGTGCTGTGACTTTGCAG were used, and for GAPDH, the forward primer $5^{\prime}$-CATCACCATCTTCCAGGA and the reverse primer 5'-CAGATCCACGACGGACA were used. The annealing temperature of the PCR was $55^{\circ} \mathrm{C}$ with 25 cycles. After PCR, $10 \mu \mathrm{l}$ PCR reaction mixture was applied to electrophoresis. The gel was stained and exposed to UV to visualize the band and captured by Gel Doc XR (BioRad). The intensity of the expected band was quantified by ImageJ (NIH). The intensity of the bands in different lanes was normalized with level of GAPDH, which served as a loading control.

In situ Hybridization

A pair of specific primers for the amplification of DLC2 riboprobe (forward primer: 5'-GGTCTGCTCTATTCACA, and reverse primer: 5'-TGCAAAGTCACAGCACATTGGCA) was designed using the free online software Primer 3 based on the published sequence of DLC2 (NM_146258.1). PCR fragments of DLC2 were generated from mouse brain cDNA and cloned into the pBluescript II SK+ vector. One microgram purified linearized DNA plasmid served as a template for RNA probe synthesis by in vitro RNA transcription with DIG labeling. The antisense or sense RNA probes were synthesized with T7 or T3 RNA polymerase, respectively, in transcription buffer $(400 \mathrm{mM}$ Tris-HCL pH 8.0, $60 \mathrm{mM} \mathrm{MgCl}_{2}, 100 \mathrm{~mm}$ dithiothreitol, $20 \mathrm{mM}$ spermidine) and DIG RNA labeling mix (Genius). The chromogenic reaction was carried out using BM purple in AP buffer.

Hot Plate Test and Tail Flick Test

The animals were tested for their response to heat stimulus [19]. Mice were placed in the bottom of a 4 liter glass beaker, which was incubated in a water bath kept at $55^{\circ} \mathrm{C}$, and the responsive time required for the mice to lick and lift their rear paws or jump was determined. The maximum time for heat stimulus was $30 \mathrm{~s}$ to avoid tissue damage of the footpad. For the tail flick test, the tail of the mice was immersed in water maintained at $52.5^{\circ} \mathrm{C}$, and the time for the mice to flick their tail was recorded as withdrawal latency. The maximum time of heat stimulus was $30 \mathrm{~s}$ to avoid tissue damage of the tail.

\section{Formalin Test}

A volume of $20 \mu \mathrm{l}$ of $1 \%$ formalin solution was injected subcutaneously through a fine-gauge needle into the ventral surface of one hind paw. The time engaged in licking and biting of the hind paw was recorded in the first $10 \mathrm{~min}$, and then between the 20 and 30-min time points. The first $10 \mathrm{~min}$, or Phase I, measured the acute pain response to the chemical. The period between 20 and $30 \mathrm{~min}$ is the Phase II pain response to inflammation.

\section{Abdominal Constriction Tests}

Mice were injected intraperitoneally with $10 \mathrm{ml} / \mathrm{kg}$ of $0.6 \%$ acetic acid or $10 \mathrm{ml} / \mathrm{kg}$ of $12 \mathrm{mg} / \mathrm{ml}$ magnesium sulfate as control. They were then placed in an observation cage, and the numbers of abdominal constrictions within the first $5 \mathrm{~min}$ or within 30 min were recorded. 


\section{Open Field Test}

Mice were placed in a $240 \times 240 \mathrm{~mm}$ transparent plastic box for assessment. A $100 \times 100 \mathrm{~mm}$ arena at the center of the box was marked. Movements were recorded by a video camera that was connected to a computer for tracking and recording. The data were analyzed with EthoVision (Noldus) software, which revealed the total time the mouse was in motion, total distance traveled, velocity, and time spent in the center arena or margin of the arena.

\section{Porsolt Swim Test}

A cylinder with a $100-\mathrm{mm}$ diameter was filled with water to a depth of at least $100 \mathrm{~mm}$. Day 1 was a training session. Mice were placed in the water-filled cylinder for $6 \mathrm{~min}$. Testing sessions were performed on Day 2. Mice were placed in the water-filled cylinder for $6 \mathrm{~min}$, and their movements were recorded by a video camera and analyzed by EthoVision (Noldus) software as described above.

\section{Measurement of Nerve Conduction Velocity}

The nerve conduction velocity (NCV) was measured in 9-11-week-old mice according to the protocol mentioned previously $[20,21]$. Briefly, mice were anesthetized with ketamine (100 $\mathrm{mg} / \mathrm{kg}) /$ xylazine $(10 \mathrm{mg} / \mathrm{kg})$, and the sciatic nerves were stimulated (5-10 V, $0.05 \mathrm{~ms}$ single square-wave pulses) proximally with platinum needle electrodes (Grass, Quincy, Mass., USA). Compound muscle action potentials were recorded from the ipsilateral foot between digits 2 and 3. Afterwards, the length of the sciatic nerve was measured. The first compound action potential from individual stimulation was used for the measurement of motor latency, while the second one was used for the measurement of sensory latency. NCV was calculated by the difference of latencies between stimulation sites [latency of M-wave (notch) - latency of M-wave (ankle)] over the length of the sciatic nerve [22].

\section{Protein Analysis Using Western Blotting}

Lumbar 4-5 spinal cords were dissected from mice $5 \mathrm{~min}, 30$ min or 1 day after the formalin injection into their footpads. Spinal cords were rinsed with ice-cold phosphate-buffered saline (PBS) and separated longitudinally through the anterior median fissure to the posterior median sulcus. The half of the spinal cord which received the injection of $\mathrm{PBS}$ or formalin was defined as the ipsilateral side, whereas the uninjected side was defined as the contralateral side. Each half of the spinal cord was lysed separately by sonication in lysis buffer (50 mM Tris $\mathrm{HCl} \mathrm{pH} \mathrm{7.4,} \mathrm{1 \%} \mathrm{NP-40,} \mathrm{0.25 \%}$ $\mathrm{Na}$-deoxycholate, $150 \mathrm{mM} \mathrm{NaCl}, 1 \mathrm{mM}$ PMSF), and $50 \mu \mathrm{g}$ of protein extract was subjected to $12 \%$ SDS-polyacrylamide gel electrophoresis (PAGE). The gel was transferred to a polyvinylidene difluoride membrane (Hybond-P; GE Healthcare). The membrane was blotted with anti-phosphorylated ERK (pERK; 1:1,000; Cell Signaling), then rescreened with anti-total ERK (1:1,000; Cell Signaling) and finally blotted with anti-GAPDH (1:1,000; Abcam). Immunoreactivity was detected with enhanced chemiluminescence according to the procedure provide by GE Healthcare.

\section{Rhotekin Binding Assay}

Tissues were lysed by sonication in lysis buffer $(50 \mathrm{mM}$ Tris $\mathrm{HCl} \mathrm{pH} 7.4,1 \% \mathrm{NP}-40,0.25 \% \mathrm{Na}$-deoxycholate, $150 \mathrm{mM} \mathrm{NaCl}$, $1 \mathrm{mM}$ PMSF). Each sample was sonicated twice for $30 \mathrm{~s}$. The lysates were spun at $13,000 \mathrm{rpm}$ for $2 \mathrm{~min}$ at $4^{\circ} \mathrm{C}$. The amount of protein was measured by BioRad protein assay. The lysates were diluted into $1 \mu \mathrm{g} / \mu \mathrm{l}$. The diluted lysates $(500 \mu \mathrm{l})$ were used for
RhoA pull-down assay. Ten microliters of cleaned agarose beads (Glutathione Sepharose 4B; GE Healthcare) was added to each sample and incubated for $1 \mathrm{~h}$ at $4^{\circ} \mathrm{C}$. The lysates were transferred to new tubes, and $50 \mu \mathrm{g}$ of GST-RBD (GST fusion protein containing RhoA-binding domain of Rhotekin) bead was added into each sample and incubated with shaking for $1 \mathrm{~h}$ at $4^{\circ} \mathrm{C}$. The supernatant was removed and the beads were washed in washing buffer three times. Bound proteins were fractionated on 12\% SDS/ PAGE and detected with polyclonal antibody for RhoA (1:1,000; Santa Cruz Biotechnology). Total tissue lysate was also analyzed with anti-RhoA antibody as a loading control. The level of active RhoA was determined after normalization with the total RhoA present in the tissue lysates.

\section{In vivo Quantification of the Cutaneous Nerve in \\ Live Animals}

The method of quantification of cutaneous nerves was according to the protocol mentioned previously [23]. Briefly, animals were anesthetized with ketamine $(100 \mathrm{mg} / \mathrm{kg}) /$ xylazine $(10 \mathrm{mg} /$ $\mathrm{kg}$ ). Hair on a defined area of the leg was removed and cleaned by PBS. Three squares of $4 \times 4 \mathrm{~mm}$ were marked on both legs: midcalf, mid-thigh and one in between those two areas. The YFPpositive small cutaneous fibers were quantitated under a fluorescent stereomicroscope. The density of all primary and secondary YFP-positive nerve fibers in these areas of the legs was expressed as average number of YFP-positive fibers per $100 \mathrm{~mm}^{2}$ (\# fibers $/ 100 \mathrm{~mm}$ ). The observer was blinded to the genotype of the experimental animals. The images of YFP-positive nerve fibers were captured by a Leica DC500 camera attached to the fluorescence stereomicroscope and processed with Leica IM 50 software.

Histological and Immunocytochemical Analysis

Footpad skins of mice were harvested and embedded in OCT. The skin samples were sectioned at $60 \mu \mathrm{m}$, mounted on poly-Llysine coated glass slides, and then dried on the drier at $37^{\circ} \mathrm{C}$ for $30 \mathrm{~min}$. The sections were washed with $1 \times$ PBS for $5 \mathrm{~min}$ and post-fixed with $4 \%$ paraformaldehyde (PFA) for $5 \mathrm{~min}$. After fixation, the sections were rinsed with $1 \times \mathrm{PBS}$ for $5 \mathrm{~min}$. The slides were mounted with FluorSave ${ }^{\mathrm{TM}}$ (Merck Ltd.) and coverslip. Five regions of the skin sections were chosen and the images of these five regions were taken by using a confocal microscope (Zeiss 510Meta). The criteria of counting small free-ending nerves were as described by Lauria et al. [24].

Lumbar 4-5 spinal cords were dissected from mice $5 \mathrm{~min}, 30$ min or 1 day after they received the $1 \%$ formalin injection into their footpads. The spinal cords were fixed in 4\% PFA for $2 \mathrm{~h}$ at room temperature and then perfused with $20 \%$ sucrose overnight at $4^{\circ} \mathrm{C}$. The cryopreserved spinal cords were sectioned at $20 \mu \mathrm{m}$ using cryostat (CM3000; Leica) and then mounted on poly-L-lysine coated glass slides.

Spinal cord sections were submerged in 4\% PFA for $20 \mathrm{~min}$ at room temperature and then washed three times in PBS for $5 \mathrm{~min}$. Diluted primary antibodies (anti-pERK1/2, 1:100; Cell Signaling) were applied and incubated at $4^{\circ} \mathrm{C}$ for $16-18 \mathrm{~h}$. The sections were then washed three times with $1 \times$ PBS for $5 \mathrm{~min}$. For pERK staining, diluted secondary antibodies (goat anti-rabbit) were applied to each section and incubated at room temperature in the dark for $60 \mathrm{~min}$. After secondary antibody incubation, the slides were washed with $1 \times$ PBS for 5 min. The ABC complex was added to each section and incubated for $30 \mathrm{~min}$ at room temperature. 
The slides were then washed with $1 \times$ PBS for 5 min. The sections were then incubated in daminobenzidine for $2 \mathrm{~min}$ and then rinsed in $1 \times$ PBS. After washing off the antibody, images were captured using a fluorescent microscope (Leica). The number of pERK-positive neurons in the superficial laminae (I-II) was measured according to the method mentioned in previous reports $[25,26]$.

\section{Morphometric Analysis of Sural Nerves}

Sural nerves of DLC2 $2^{+/+}$and DLC2 ${ }^{-/-}$mice were harvested and fixed in primary fixative overnight at $4^{\circ} \mathrm{C}$. Then, the tissues were rinsed in $0.1 \mathrm{M}$ PBS three times for $5 \mathrm{~min}$. The tissues were postfixed in $1 \%$ osmium tetroxide for $2 \mathrm{~h}$ at $4^{\circ} \mathrm{C}$. After post-fixation, the tissues were rinsed in $0.1 \mathrm{M}$ PBS three times for $5 \mathrm{~min}$. After washing, the tissues were dehydrated in ascending ethanol series. After dehydration, tissues were infiltrated with propylene oxide, and propylene oxide:Epon (50:50) for $1 \mathrm{~h}$. Tissues were transferred to $100 \%$ Epon on a rotator overnight, embedded in Epon and polymerized in $60^{\circ} \mathrm{C}$ for $72 \mathrm{~h}$. The $1-\mu \mathrm{m}$-thick transverse sections of nerves were cut using Ultracut (Reichert-Jung, Leica) mounted on TESPA-coated glass slides and counter-stained with toluidine blue. The photomicrographs of the sural nerves were taken at a magnification of $1,000 \times$ using a computer-assisted image analyzing system (SPOT). The fascicular area, Feret diameter, and myelinated fiber number and size were analyzed and measured by Image $(\mathrm{NIH})$.

\section{Statistical Analysis}

All data were expressed as means \pm SEM. Statistical analysis was performed by Student's t test, Mann-Whitney test or one-way ANOVA. p values of 0.05 were considered statistically significant.

\section{Results}

DLC2 mRNA Is Expressed in Brain, Spinal Cord and Sciatic Nerve Tissue

To analyze the role of DLC2 in the neural control of pain, gene expression in brain, spinal cord and peripheral nerve tissue was analyzed using semi-quantitative RT-PCR. As shown in figure 1A, DLC2 mRNA was present in each tissue and, as expected, absent in the corresponding tissues from DLC2 ${ }^{-/-}$mice. Within the brain, DLC2 expression was high in the cortex, cerebellum, hippocampus, and brainstem and low in the midbrain and olfactory bulb. In situ hybridization confirmed that DLC2 mRNA is localized in neurons of $\mathrm{DLC}^{+/+}$mice in the above-mentioned regions, and expression was not detected in these areas in $\mathrm{DLC} 2^{-/-}$mice (fig. 1B).

\section{Increased RhoA Activity in Nerve Tissues of \\ DLC2-Deficient Mice}

The role of DLC2 as a RhoGAP specific for RhoA was established using cell lines [11, 27]. However, this function has not been confirmed in animal tissues. Therefore,
RhoA activity in the brain and the peripheral nerves of $\mathrm{DLC}^{+/+}$and $\mathrm{DLC}^{-/-}$mice was assessed using the Rhotekin binding assay $[11,27]$. Significant differences in RhoA activity were not found in the brain tissue of $\mathrm{DLC}_{2}^{+/+}$and $\mathrm{DLC}^{-/-}$mice $(\mathrm{n}=5)$ (fig. $\left.1 \mathrm{C}-\mathrm{b}\right)$. Interestingly, RhoA activity was significantly increased in the peripheral nerves of $\mathrm{DLC}^{-/-}$mice compared to that of $\mathrm{DLC}^{+/+}$mice (fig. 1C-d).

\section{DLC2-Deficient Mice Experience More Severe Hyperalgesia}

Because RhoA has been implicated in pain sensation and the regions of the brain in which DLC2 was highly expressed have been linked to pain processing pathways [28-32], we investigated whether DLC2 is involved in pain sensation. We compared the response of 9-11-weekold $\mathrm{DLC}^{+/+}$and DLC2 $2^{-/-}$mice to noxious thermal stimuli and inflammatory chemical-induced pain. In the hot plate and tail flick tests, DLC2-deficient mice showed shorter paw and tail withdrawal latencies than the $\mathrm{DLC}^{+/+}$mice, suggesting that the former were more sensitive to painful thermal stimuli (fig. 2a, b).

An injection of $1 \%$ formalin to the right hind paw causes the mouse to lick and bite its paw and flinch its leg. Such behavioral responses occur within $10 \mathrm{~min}$ (Phase I) and within 20-30 min (Phase II) after the formalin injection. Phase I is also referred to as the acute phase, whereas Phase II is often referred to as inflammation-induced pain phase. During Phase I, the frequency of licking and flinching in DLC2 ${ }^{-/}$mice was not different from that in $\mathrm{DLC2}^{+/+}$mice. However, DLC2 $2^{-/-}$mice showed a significantly more intense Phase II pain response than the $\mathrm{DLC} 2^{+/+}$mice. These mice spent more time biting, licking or flinching their right hind paw (fig. 2d). The enhanced response to inflammatory pain in the formalin-injected $\mathrm{DLC} 2^{-/-}$mice was not due to more severe inflammation, as both $\mathrm{DLC}^{-/-}$and $\mathrm{DLC}^{+/+}$ mice showed a similar degree of swelling in the right hind paw (data not shown).

An intraperitoneal injection of acetic acid and magnesium sulfate produces acute inflammatory pain and acute non-inflammatory, prostaglandin-independent pain, respectively [33]. In response to the acetic acid injection, DLC2 ${ }^{-/-}$mice showed significantly more abdominal constriction than $\mathrm{DLC} 2^{+/+}$mice (fig. 2e). In contrast, injection of magnesium sulfate resulted in a similar response in the $\mathrm{DLC}^{-/-}$and $\mathrm{DLC}^{+/+}$mice (fig. $2 \mathrm{f}$ ).

Neurosignals 2012;20:112-126 


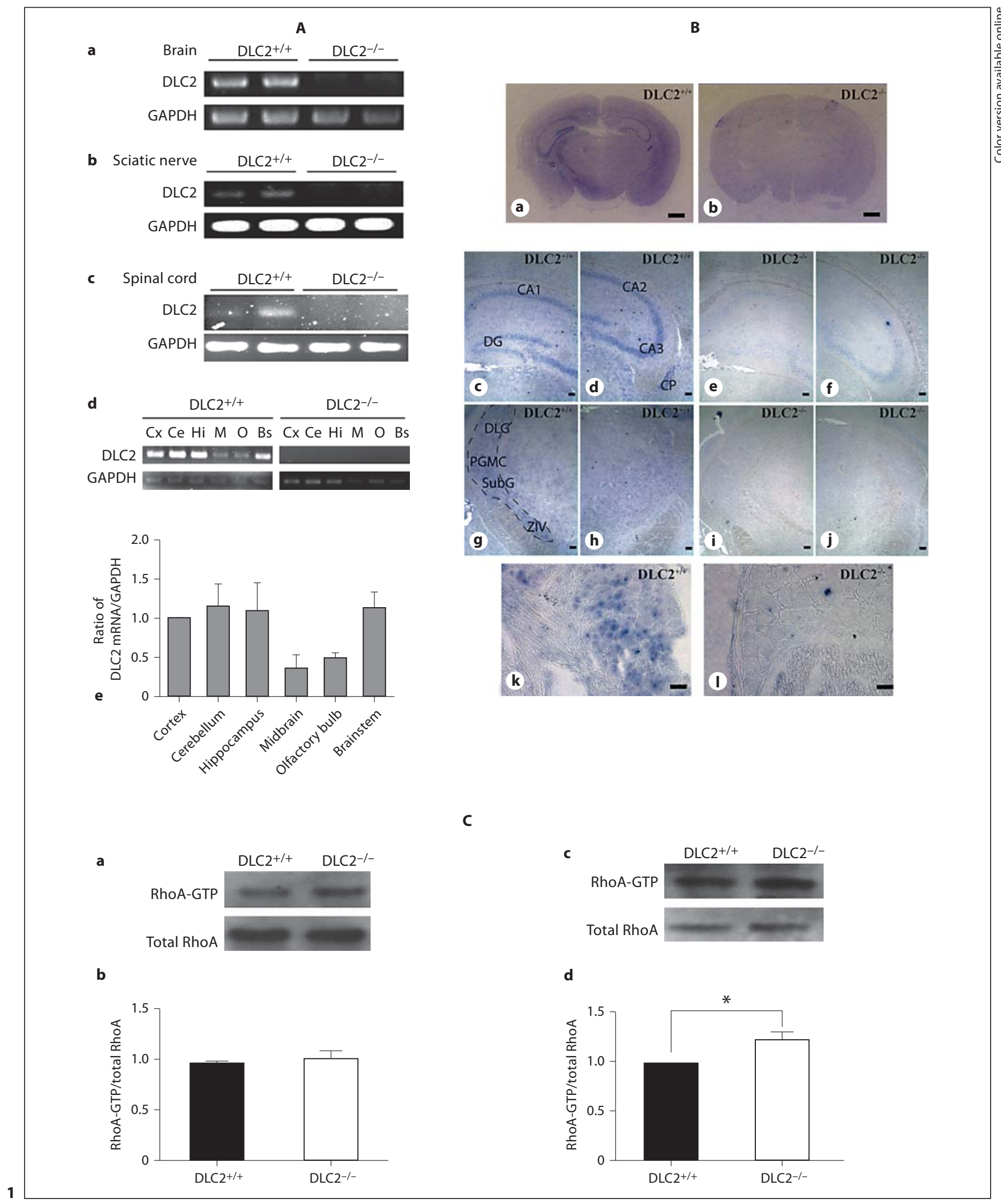

(For legend see p. 118.) 

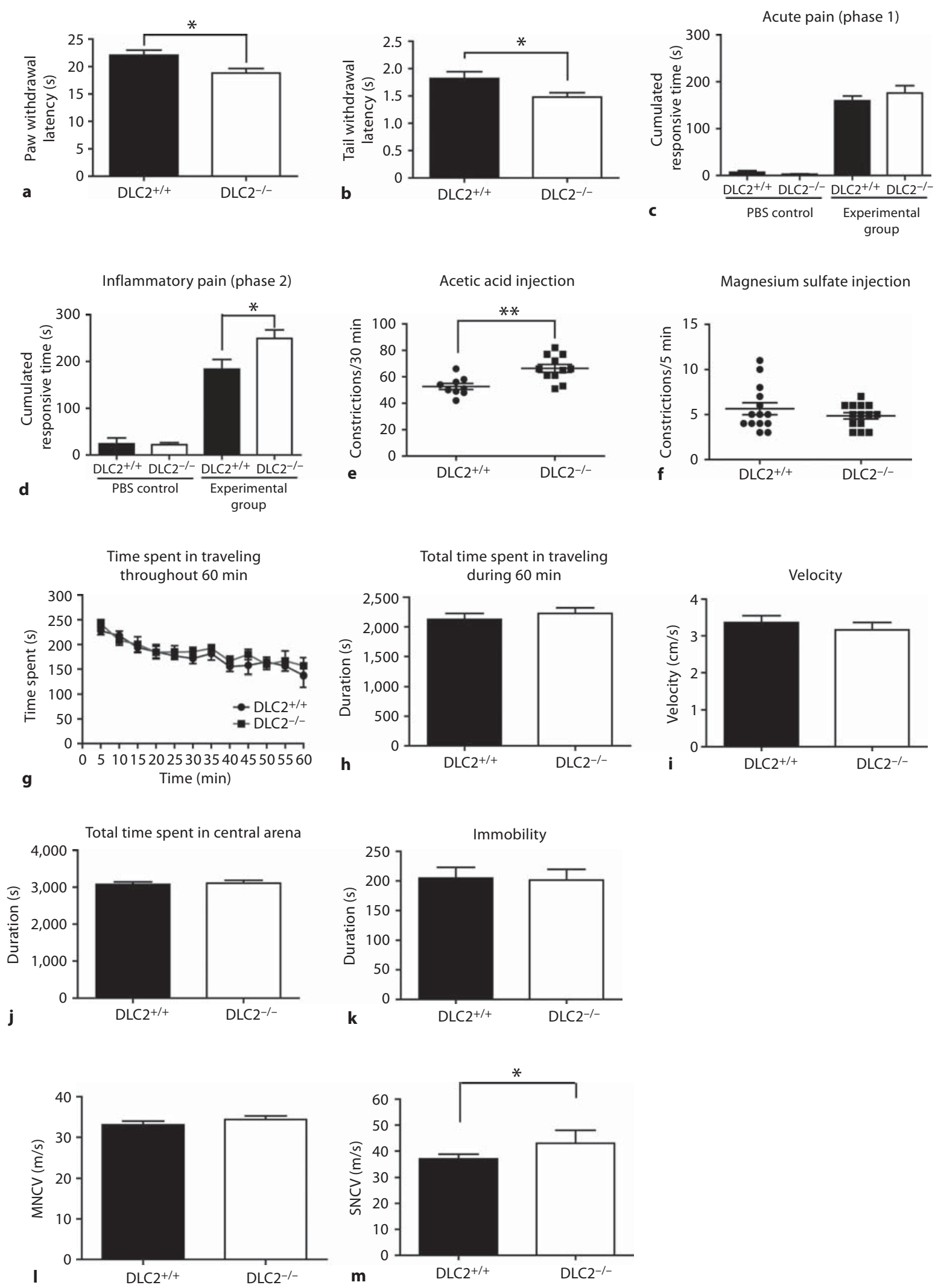

(For legend see p. 118.) 


\section{DLC2-Deficient Mice Have Normal Locomotor} Activity and Do Not Exhibit Anxiety or Depressive Behaviors

DLC2 expression was analyzed in the hippocampus and the zona incerta, which are involved in locomotor activity, anxiety, depressive-like behavior, and pain modulation. In addition, anxiety is one of the potential components of pain response [34]. Therefore, we examined $\mathrm{DLC}^{-/-}$mice to determine whether they have any abnormalities in locomotor function, anxiety, or depressive behavior.

(For figures 1 and 2, see pp. 116-117.)

Fig. 1. Disruption of the DLC2 gene results in a loss of DLC2 mRNA expression determined by semi-quantitative RT-PCR and visualized by in situ hybridization. A Semi-quantitative RT-PCR showing the expression of DLC2 in the brain (a), sciatic nerve (b) and spinal cord (c) of $\mathrm{DLC}^{+/+}$mice, which was absent in DLC2 $2^{-/-}$mice. Photomicrographs showing DLC2 mRNA in various brain regions $(\mathrm{n}=3)(\mathbf{d})$, which was absent in all brain regions of DLC2 $2^{-/}$mice. The expression of DLC 2 mRNA was normalized with GAPDH. $\mathrm{Cx}=$ Cortex; $\mathrm{Ce}=$ cerebellum; $\mathrm{Hi}=$ hippocampus; $\mathrm{M}=$ middle part of the brain; $\mathrm{O}=$ olfactory bulb; $\mathrm{Bs}=$ brain stem . Data are shown as mean \pm SEM. B Photomicrographs showing DLC2 mRNA expression in the whole brain of DLC2 $2^{+/+}$mice (a), which was absent in the brain of $\mathrm{DLC}^{-1-}$ mice (b). Scale bar: $1 \mathrm{~mm}$. High-magnification photomicrographs showing DLC2 mRNA expression in the hippocampus (c, $\mathbf{d ~ D L C 2} 2^{+/+}$and $\mathbf{e , ~} \mathbf{f}$ DLC2 $\left.2^{-/-}\right)$and the thalamus $\left(\mathbf{g}, \mathbf{h} \mathrm{DLC}^{+/+}\right.$and $\mathbf{i}, \mathbf{j}$ DLC2 $\left.2^{-/-}\right)$. Scale bar: $10 \mu \mathrm{m}$. CA1 = Field CA1 hippocampus; CA2 = field CA 2 hippocampus; $\mathrm{CA} 3$ = field CA3 hippocampus; $\mathrm{DG}=$ dentate gyrus; $\mathrm{CP}=$ choroids plexus; $\mathrm{DLG}=$ dorsal lateral geniculate nuclei; $\mathrm{PGMC}=$ pre-geniculate nucleus magnocellular part; $\mathrm{SubG}=$ subgeniculate nuclei; ZIV = zona incerta ventral. Photomicrographs showing mRNA localization in DRG of $\mathrm{DLC}^{+/+}(\mathbf{k})$ and $\mathrm{DLC}^{-/-}$ mice (I). Scale bar: $10 \mu \mathrm{m}$. C Micrographs showing Western blotting of RhoA pull-down assay from the brain (a) and peripheral nerves (including the brachial plexus and sciatic nerves; c) of $\mathrm{DLC}^{+/+}$and DLC2 $2^{-/-}$mice. Upper band shows RhoA level after pulling down (RhoA-GTP) and lower band shows total RhoA in the protein extract. Histogram showing the quantification of active RhoA in the brain (b) and peripheral nerves (d) of $\mathrm{DLC}^{+/+}$ and DLC2 ${ }^{-/-}$mice, which was normalized by total RhoA in the extract $(n=5)$. Data are expressed as mean \pm SEM. ${ }^{*} p<0.05$ by Mann-Whitney test.

Fig. 2. Pain perception tests in $\mathrm{DLC}^{+/+}$and $\mathrm{DLC}^{-/-}$mice. a Histogram showing hot plate test in 9-11-week-old $\mathrm{DLC}^{+/+}$and DLC2 $^{-/-}$mice $(\mathrm{n}=15)$. b Histogram showing tail flick test in $\mathrm{DLC}^{+/+}$and DLC2 $2^{-/-}$mice $(\mathrm{n}=13)$. $\mathbf{c}$ Histogram showing formalininduced pain response in the acute pain phase, which is $10 \mathrm{~min}$ after injection. $\mathbf{d}$ Histogram showing formalin-induced pain response in the inflammatory pain phase, which is $20-30 \mathrm{~min}$ after injection. PBS control group: $\mathrm{n}=3$; experimental group: $\mathrm{n}=10$. e Scatter plot showing the number of abdominal constrictions within $30 \mathrm{~min}$ af-
In the open field test, which examines general exploratory and locomotor activity, no significant differences in the total duration of locomotor activity and total distance traveled within $1 \mathrm{~h}$ were observed between $\mathrm{DLC}^{-/-}$and $\mathrm{DLC}^{+/+}$mice, suggesting that the loss of DLC2 expression did not affect habituation (fig. $2 \mathrm{~g}$, h). In addition, no significant difference in the moving velocity was observed between the mice, suggesting that locomotor activity was not affected by DLC2-deficiency (fig. 2i). Furthermore, no differences in the time spent in the center of the test field were observed, suggesting that each genotype had a normal level of anxiety (fig. 2j).

ter injection of $0.6 \%$ acetic acid i.p. in $\mathrm{DLC}^{+/+}(\mathrm{n}=9)$ and DLC2 ${ }^{-/-}$ mice $(\mathrm{n}=11)$. $\mathbf{f}$ Scatter plot showing the number of abdominal constrictions within $5 \mathrm{~min}$ after injection of $120 \mathrm{mg} / \mathrm{kg}$ magnesium sulfate $(\mathrm{n}=14)$. $\mathbf{g}$ Graph showing the time spent in traveling of 9-11-week-old DLC2 $2^{+/+}$and DLC2 $2^{-/}$mice in the open field test $(\mathrm{n}=7)$. Histograms showing the total time spent in traveling during $60 \mathrm{~min}(\mathbf{h})$, the velocity during $60 \mathrm{~min}$ (i), and the total time spent in the central arena in the open field test (j) of 9-11-week-old mice $(\mathrm{n}=7)$. $\mathbf{k}$ Histogram showing time spent immobile in the Porsolt swim test. Histograms showing the MNCV (I) and SNCV (m) of 9-11-week-old DLC2 ${ }^{+/+}$and DLC2 $2^{-/-}$mice $(\mathrm{n}=10)$. Data are expressed as mean \pm SEM. ${ }^{*} \mathrm{p}<0.05,{ }^{* *} \mathrm{p}<0.01$ by Mann-Whitney test.

Fig. 3. Morphological study in nerves of $\mathrm{DLC} 2^{-/-}$mice. Morphological analysis of sural nerve in $\mathrm{DLC} 2^{+/+}$and $\mathrm{DLC} 2^{-/-}$mice: semithin sections of sural nerves of $\mathrm{DLC}^{+/+}(\mathbf{a})$ and $\mathrm{DLC}^{-/-}$(b) mice (scale bar: $10 \mu \mathrm{m}$ ) were stained with toluidine blue. Histograms showing the mean of the fascicular area of the sural nerve (c), the mean of the fascicular diameter of the sural nerve (d), the mean of the total number of myelinated fibers (e), the mean of the myelinated fiber density of the sural nerve (f), the diameter of myelinated fibers in the sural nerve (g), the area diameter of the axon (h), the thickness of myelin in myelinated fibers (i), and the area of unmyelinated fibers (j). Data are expressed as mean \pm SEM. $\mathrm{n}=5$ in each group of animals. $\mathbf{k}$ Photomicrographs showing the cutaneous YFP fibers in the leg (i). The insets on the right-hand panel (ii and iii) show the magnified images of the boxed areas (1 and 2, respectively). The white arrowheads point to the primary small fibers, and the white arrows point to the secondary small fibers. The red arrowheads point to large nerve fibers in the dermis parallel to the skin surface. I Histogram showing the cutaneous small fiber density of DLC2 $2^{+/+}$and DLC2 $2^{-/-}$mice. $\mathrm{n}=7$ in each group of animals. Each column shows mean \pm SEM. Scale bar: $100 \mu \mathrm{m}$. $\mathbf{m}$ Photomicrographs showing the cutaneous YFP small fibers in the skin section of the plantar surface of DLC2 $2^{+/+} /$Thy1.2YFP (i) and DLC2 $2^{-/} /$Thy1.2-YFP (ii) mice. The white arrows point to the representative free-ending cutaneous YFP small fibers. $\mathbf{n}$ Histogram showing the cutaneous small fiber density of $\mathrm{DLC}^{+/+}$and $\mathrm{DLC} 2^{-/-}$mice. Data are expressed as mean \pm SEM. $\mathrm{n}=7$ in each group of animals. k.l. = Keratin layer; ep. $=$ epidermis, d. = dermis. Scale bar: $50 \mu \mathrm{m}$. 


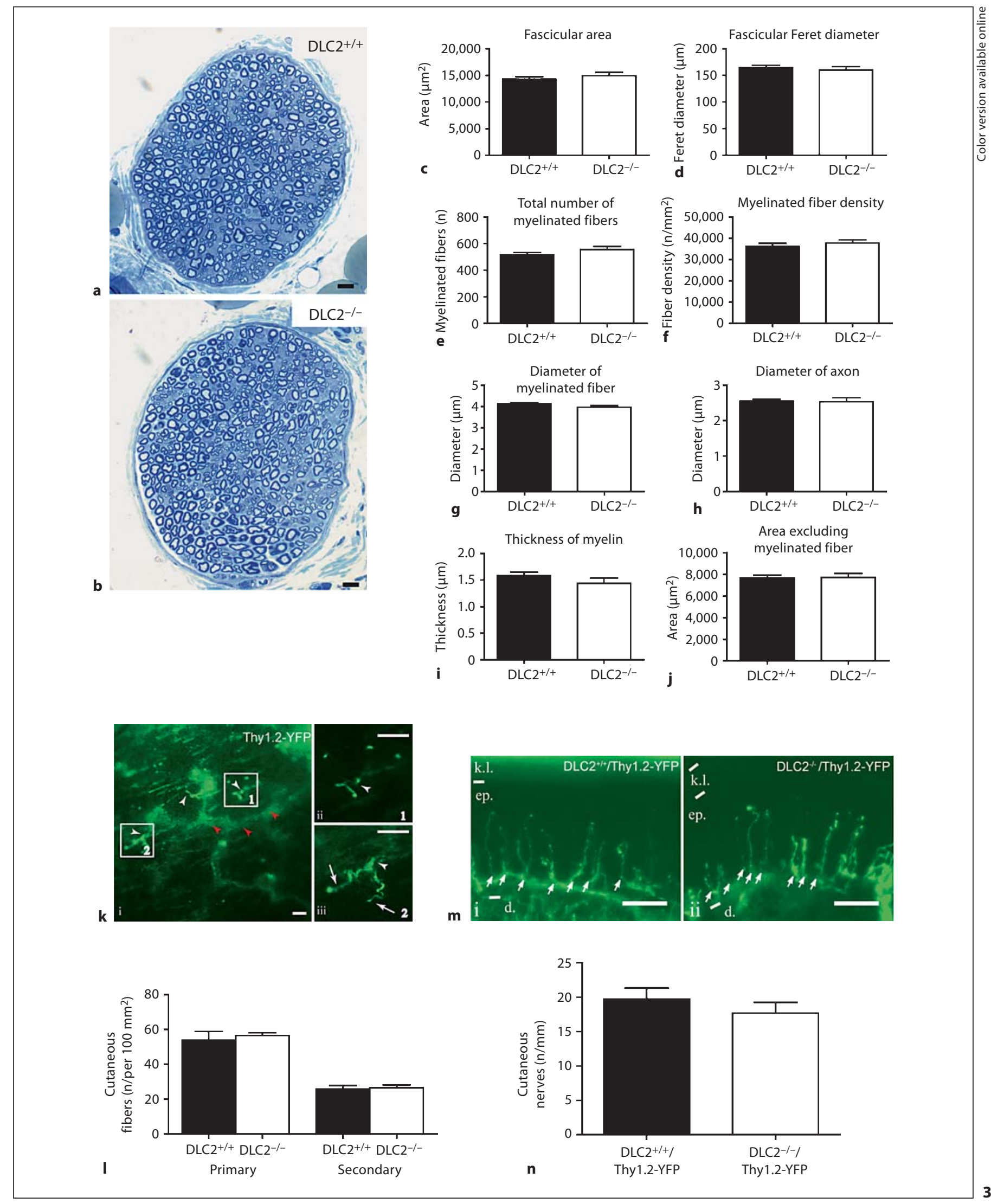

DLC2 Modulates RhoA Activity and

Neurosignals 2012;20:112-126 
In the Porsolt swim test, which is designed to reveal depression-like behavior [33, 35], DLC2 ${ }^{-/-}$mice behaved similar to $\mathrm{DLC}^{+/+}$mice in terms of the amount of struggling time and the amount of time spent floating (fig. $2 \mathrm{k}$ ). An increase in the floating time is indicative of depression because mice stop trying to get out of the water.

\section{DLC2-Deficient Mice Show Increased Sensory NCV,} but the Sural Nerve Morphology Appears Normal

Sensory NCV (SNCV) and motor NCV (MNCV) in the sciatic nerve of 9-11-week-old DLC2 $2^{+/+}$and DLC2 $2^{-/-}$ mice were determined as described in the Animals and Methods section. The $\mathrm{DLC} 2^{-/-}$mice $\mathrm{MNCV}$ appeared normal (fig. 2l); however, the SNCV was increased compared to that of $\mathrm{DLC}^{+/+}$mice (fig. $2 \mathrm{~m}$ ).

Because only the SNCV was affected in $\mathrm{DLC}^{-/-}$mice, the sensory nerve morphology (i.e. sural nerve) of the $\mathrm{DLC}^{+/+}$and $\mathrm{DLC}^{-/-}$mice was examined (fig. $3 \mathrm{a}, \mathrm{b}$ ). Semi-thin $(1 \mu \mathrm{m})$ sections of the sural nerve were prepared, and morphometric analysis of the myelinated fibers was performed because these fibers are likely to affect NCV. The results showed no difference in the fascicular area and minimum Feret diameter (fig. 3c, d), the number and density of myelinated fibers (fig. 3e, f), axon diameter (fig. 3g, h), and thickness of myelin (fig. 3i) between DLC2 $2^{-/-}$and $\mathrm{DLC}^{+/+}$mice. In addition, the area of unmyelinated fibers was not significantly different between $\mathrm{DLC}^{+/+}$and DLC2 ${ }^{-/}$mice (fig. 3j). Taken together, these data suggest that the loss of DLC2 does not affect sural nerve morphology.

\section{The Number of Cutaneous Nerve Fibers Is Not}

Different between $\mathrm{DLC} 2^{+/+}$and $\mathrm{DLC2} 2^{-/-}$Mice

A transgene that labels nerve fibers with YFP [23] was introduced into $\mathrm{DLC}_{2}^{+/+}$and $\mathrm{DLC}^{-/-}$mice to facilitate non-invasive visualization of cutaneous nerve fibers. Both small and large YFP-labeled fibers in the skin can be visualized under the fluorescent microscope (fig. 3k). Large nerve fibers were found in the dermis parallel to the skin surface (fig. 3ki, red arrowhead). The small fibers (fig. 3ki, white arrowhead) in the epidermal layer perpendicular to the skin surface were cutaneous nerves. The nerves that branched out from the large fibers were termed primary fibers (fig. 3kii, white arrowhead), whereas those bifurcating from the primary fibers (fig. 3kiii, white arrow) were termed secondary fibers. Non-invasive microscopic visualization was unable to distinguish between myelinated and unmyelinated fibers.

We quantified the cutaneous nerve fiber density in three regions of the thigh in 9-11-week-old $\mathrm{DLC}^{+/+}$YFP and DLC2 $2^{-/}$YFP mice [23]. As shown in figure 31, there was no significant difference in the primary and secondary cutaneous nerve fibers between $\mathrm{DLC}^{+/+}$and DLC2 $2^{-/-}$ mice. The cutaneous nerve fiber density within the epidermis and perpendicular to the dermis in five regions of the footpad skin was also examined and also showed no difference between $\mathrm{DLC}^{+/+}$and DLC2 $2^{-/}$mice (fig. $3 \mathrm{~m}, \mathrm{n}$ ).

\section{RhoA Activity in the Spinal Cord of DLC2-Deficient}

Mice Is Increased 30 Min after a Formalin Injection

To determine whether RhoA was involved in the Phase II hyperalgesia response in DLC2 ${ }^{-/-}$mice, RhoA activity in the spinal cord $30 \mathrm{~min}$ after the formalin injection was determined. In $\mathrm{DLC}^{+/+}$mice, the RhoA activity was not different between the ipsilateral (same side as formalin injection) and contralateral (opposite side of formalin injection) side of the L1-S1 spinal cord (fig. 4). In DLC2 ${ }^{-/-}$ mice, a significant increase in RhoA activity was observed in the ipsilateral side of the spinal cord compared to the contralateral side (fig. $4 \mathrm{~b}$ ).

\section{The Number of pERK1/2-Positive Cells in the Spinal Dorsal Horn Is Increased}

Phosphorylation of ERK in the spinal dorsal horn is thought to play an important role in the inflammatory pain response [36]. To determine whether ERK1/2 is involved in hyperalgesia in DLC2 $2^{-/}$mice, spinal cords were dissected 5 and $30 \mathrm{~min}$ after a formalin injection and were stained with antibodies against pERK1/2.

In naïve $\mathrm{DLC}^{+/+}$and $\mathrm{DLC2}^{-/-}$mice, the number of pERK1/2-positive cells in the superficial layer of the spinal dorsal horn was not significantly different (fig. 5a). The number of pERK1/2-positive cells in the ipsilateral dorsal horn of $\mathrm{DLC}^{+/+}$mice was significantly increased $5 \mathrm{~min}$ after the injection in comparison to the contralateral side (fig. 5ai, aii). The number of pERK1/2-positive cells in the ipsilateral side of $\mathrm{DLC}^{-/-}$mice was also significantly higher in comparison to the contralateral side (fig. 5aiii, aiv); however, the degree of the increase was much higher than that in $\mathrm{DLC}^{+/+}$mice (fig. 5ai, aiii, di). At 30 min after the formalin injection, the number of pERK1/2-positive cells in the superficial spinal dorsal horn was reduced in both the contralateral and ipsilateral sides in $\mathrm{DLC}^{+/+}$and DLC2 ${ }^{-/-}$mice (fig. $5 c$, dii), and no significant difference in the number of pERK1/2-positive cells was observed.

Western blot analysis confirmed that the pERK1/2 level in the ipsilateral spinal cord of $\mathrm{DLC2} 2^{-/}$mice was significantly higher than that of $\mathrm{DLC}^{+/+}$mice (fig. 5diii, div). However, the difference in pERK1/2 expression between the contralateral and ipsilateral spinal cord of 


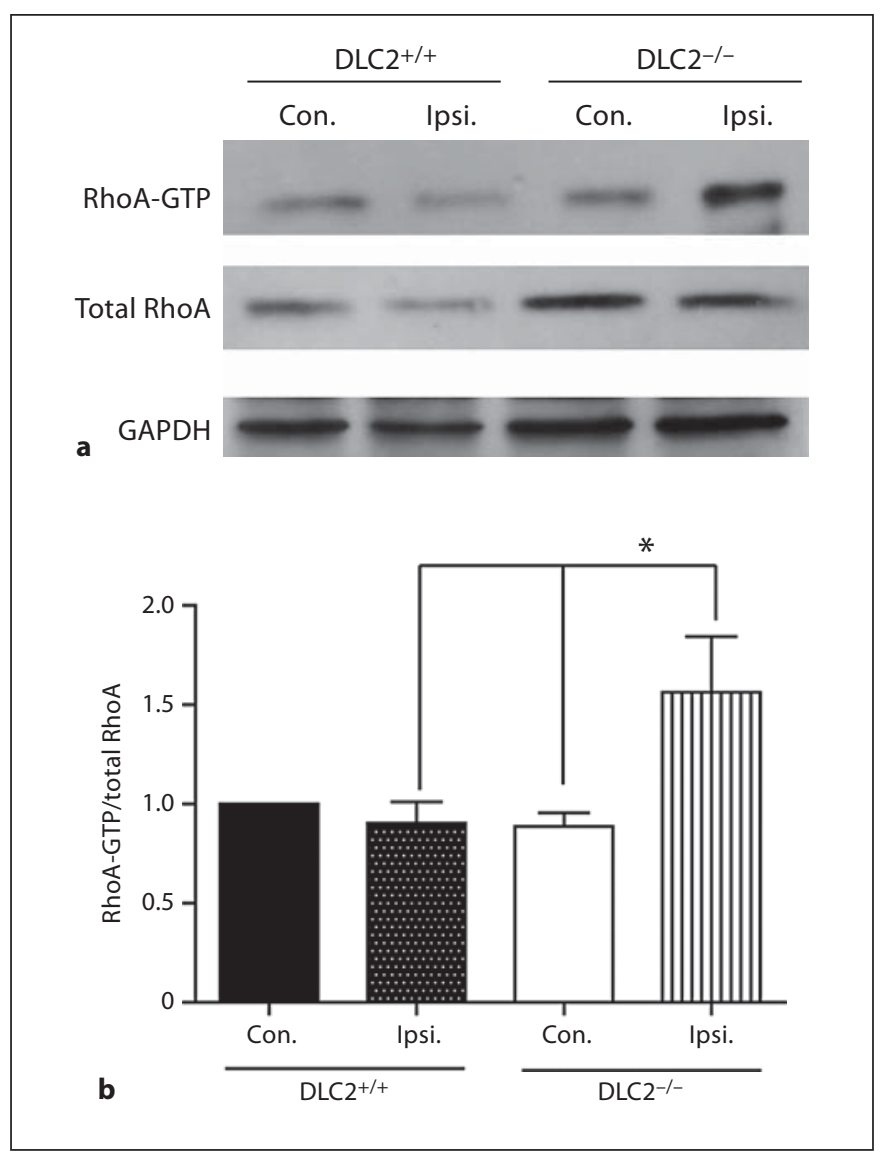

Fig. 4. RhoA activity assay in DLC2 $2^{+/+}$and $\mathrm{DLC} 2^{-/-}$mice $30 \mathrm{~min}$ after formalin injection. a Photograph showing Western blotting results of RhoA activity. Upper panel shows the level of active RhoA (RhoA-GTP), middle panel shows the level of total RhoA in lysate and lower panel shows the level of GAPDH in total lysate. b Histogram showing quantification of RhoA activity after formalin injection. The RhoA activity was normalized with total RhoA in lysate. $\mathrm{n}=8$ in each group. Data are expressed as mean \pm SEM. ${ }^{*} \mathrm{p}<0.05$ by one-way ANOVA. Con. $=$ Contralateral side of the spinal cord; Ipsi. = ipsilateral side of the spinal cord.

$\mathrm{DLC}^{+/+}$mice and the difference of $\mathrm{pERK} 1 / 2$ expression between the contralateral and ipsilateral spinal cord of $\mathrm{DLC}^{-/-}$mice was not observed in the quantitative Western blot histogram.

\section{Discussion}

Loss of DLC2 Does Not Affect Locomotor Activity, Anxiety, and Depression

In this report, we showed that DLC2-null mice were more sensitive to noxious thermal stimuli and chemical- ly induced inflammatory pain. DLC2 is a newly identified RhoGAP specific for RhoA [1, 11]. Several RhoGAPs are thought to be involved in neuronal morphogenesis. Oligophrenin-1 appears to play a role in neurite outgrowth and the regulation of synaptic connectivity [37].p250GAP, which is a RhoGAP for RhoA and Cdc42, is enriched in the NMDA receptor complex and regulates dendritic spine structure in an NMDA receptor-dependent manner [38]. DLC1 is also a RhoGAP specific for RhoA and Cdc42 [39] and is thought to be involved in neural tube development. DLC1-null mice die in utero due to defects in neural tube development [40]. One of the RhoGAPs, p190GAP, is involved in axon guidance and fasciculation [41]. Interestingly, DLC2-null mice appeared normal with no obvious abnormality in the nervous tissues. Their locomotor activity appeared normal, without exhibiting any signs of anxiety-like or depression-like behavior in the open field test and Porsolt swim test, respectively. The morphology of the cutaneous nerves, such as the sural nerve, appeared normal.

\section{More Severe Hyperalgesia Is Observed in DLC2-Deficient Mice}

Interestingly, $\mathrm{DLC}^{-/-}$mice were more sensitive to noxious thermal stimuli and inflammatory pain than $\mathrm{DLC}^{+/+}$mice. A hyperalgesic response to noxious thermal stimuli was observed in the hot plate and tail flick tests. In addition, a hyperalgesic response to inflammatory pain was determined by quantifying the Phase II response during a formalin test. The abdominal constriction response to an inflammatory agent was also determined. DLC2 $2^{-/}$mice were hypersensitive to acetic acid-induced (inflammatory) pain, whereas they exhibited a normal response to magnesium sulfate-induced (non-inflammatory acute) pain. Hyperalgesia to inflammatory pain in $\mathrm{DLC}^{-/-}$mice was not due to increased inflammation in the injected footpads, as the swelling of the injected footpads was not significantly different from that of the DLC2 $2^{+/+}$mice (data not shown). Taken together, these observations indicate that DLC2 is involved in the modulation of pain sensation. DLC2 expression was present in several regions of the brain that are involved in pain modulation, including the hippocampus CA1 region [31], dentate gyrus [42], and zona incerta [43].

\section{SNCV Is Increased in DLC2 $2^{-/-}$Mice}

$\mathrm{DLC} 2^{-/-}$mice showed a normal MNCV, although the $\mathrm{SNCV}$ was increased compared to that of $\mathrm{DLC}^{+/+}$mice. The SNCV measured in this study was the conduction 


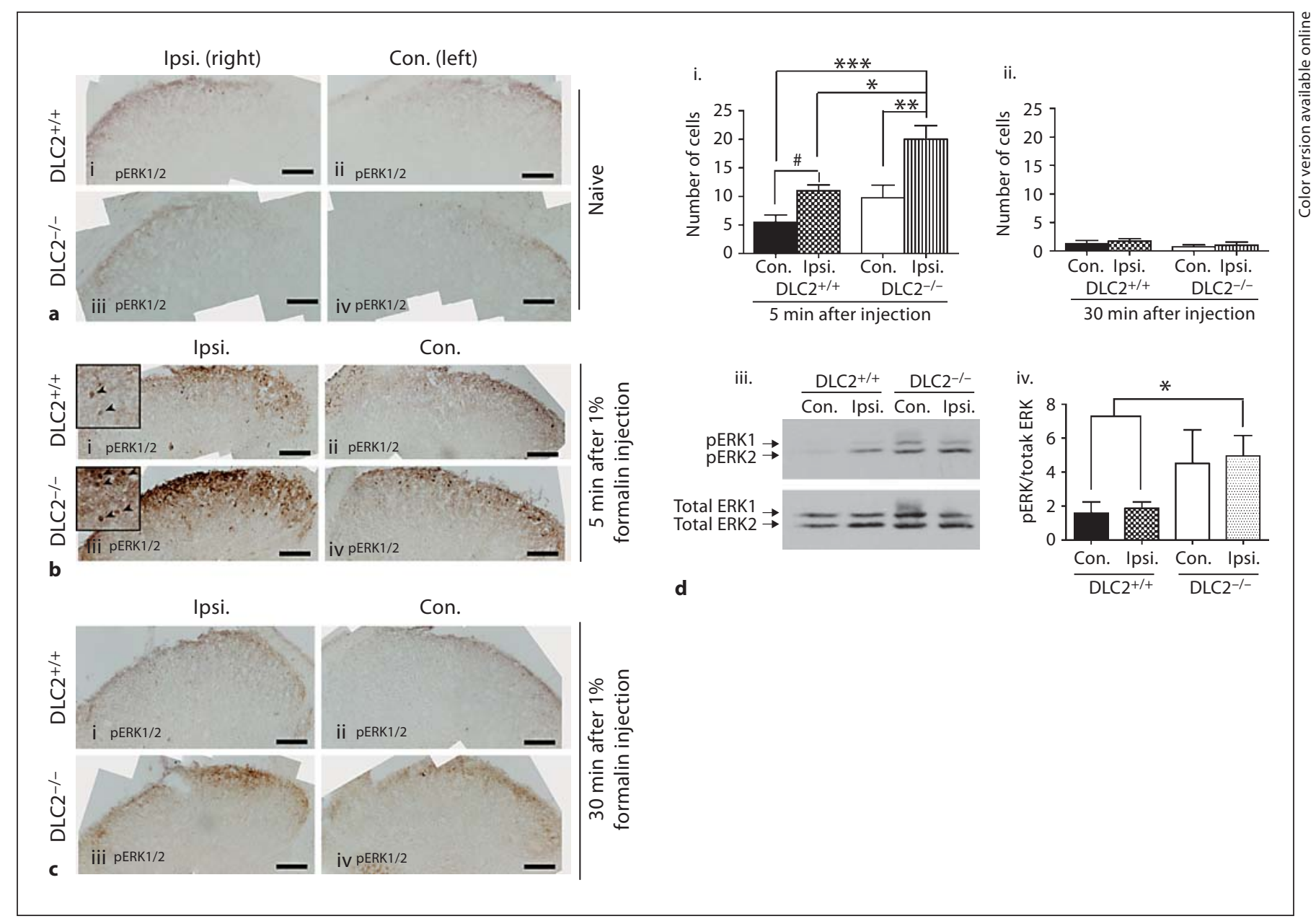

Fig. 5. pERK immunoreactivity in the superficial dorsal horn of the spinal cord after $1 \%$ formalin injection. a-c Representative micrographs showing the superficial dorsal horn of the spinal cord in $\mathrm{DLC}^{+/+}(\mathrm{i}, \mathrm{ii})$ and DLC2 $2^{-/}$(iii, iv) mice with pERK1/2 immunocytochemical staining in naïve condition (a), 5 min after formalin injection (b) and $30 \mathrm{~min}$ after formalin injection (c). No obvious pERK1/2-stained cells were found on both sides of the superficial dorsal horn in $\mathrm{DLC}^{+/+}$(ai and aii and $\mathrm{DLC}^{-/-}$(aiii and aiv) mice in naïve condition. The number of pERK-positive cells (indicated with arrowheads in the insets of bi and biii) was

velocity of a $\mathrm{H}$-reflex, which runs from the sensory nerves to the spinal cord and back to the motor nerves [44]. A faster SNCV may thus contribute to a shorter withdrawal latency in the hot plate test and the tail flick test. Increased RhoA activity in the peripheral nerves of DLC2 $2^{-/-}$mice may also contribute to the hypersensitivity to thermal stimuli, as the activation of RhoA and ROCK induce neurotransmitter release through a reorganization of the actin cytoskeleton [14].

quantified in the ipsilateral (bi, biii, ci, ciii) and contralateral (bii, biv, cii, civ) sides of the dorsal horn spinal cord. d Histogram showing the quantitation of pERK-positive cells in the superficial dorsal horn $5 \mathrm{~min}$ (di) or $30 \mathrm{~min}$ (dii) after 1\% formalin injection. $\mathrm{n}=4$ in each group. Scale bar: $100 \mu \mathrm{m}$. diii Photomicrograph showing the Western blotting of pERK in the spinal cord 5 min after formalin injection. div Histogram showing the ratio of pERK1/2 (both bands of pERK1/2) to total ERK1/2. Data were expressed as mean \pm SEM. ${ }^{*} \mathrm{p}<0.05$; ${ }^{* *} \mathrm{p}<0.01$, ${ }^{* *} \mathrm{p}<0.001$ by one-way ANOVA; ${ }^{*} \mathrm{p}<0.05$ by Student's t test.

The increased SNCV in DLC2 ${ }^{-/}$mice was not associated with a noticeable change in the structure of the sural nerves. The fascicular area, the number of myelinated fibers and the axon diameter were similar in both the $\mathrm{DLC}^{+/+}$and DLC2 $2^{-/-}$mice. Unfortunately, the resolution of the sural nerve semi-thin sections was not sufficient to reveal the morphology of the unmyelinated fibers. The area of the unmyelinated fibers in the sural nerves was determined by deducing the fascicular area by the area of 
the myelinated fibers. The area of the unmyelinated fibers in the sural sections was not significantly different between $\mathrm{DLC}^{+/+}$and $\mathrm{DLC}^{-/-}$mice. Our data suggest that $\mathrm{DLC}^{-/-}$mice have normal sural nerve morphology and myelination.

In addition to the nerve structure, the post-synaptic release of nitrite oxide (NO) and its subsequent diffusion play an important role in synaptic plasticity and longterm potentiation [45]. ROCK regulates $\mathrm{NO}$ release through the stimulation of prostaglandin E2 [46]. Determining NADPH-diaphorase and nNOS activity in $\mathrm{DLC}^{-/-}$mice would shed light on the role of RhoA in NCV. Moreover, RhoA activation induces the release of neurotransmitters such as glutamate through the reorganization of the actin cytoskeleton at the cell periphery by activating ROCK and myristoylated alanine-rich C-kinase substrate (MARCKS) [17]. The increase in pre-synaptic RhoA activity also induced acetylcholine release in Caenorhabditis elegans through an unknown mechanism [18]. Therefore, increased SNCV in DLC2 ${ }^{-/-}$mice may be the result of altered synaptic connectivity and function, although further studies are required to support this hypothesis.

\section{RhoA Activity Is Increased in the Spinal Cord of}

DLC2 ${ }^{-/-}$Mice after a Formalin Injection

The injection of formalin into the rodent hind paw produces two distinct phases of nociceptive behavior. These two pain phases involve different physiological mechanisms. The Phase I pain response occurs during the chemical activation of primary afferent nociceptors at the injection sites, whereas the Phase II pain response is the result of factors released from local inflammation at the injection site. In this study, the $\mathrm{DLC}^{-/-}$mice displayed a hyperalgesic Phase II response after the formalin injection, indicating that DLC2 may modulate inflammatory pain. This phenotype was confirmed by the acetic acid abdominal contraction test (fig. 2e), which is another inflammatory pain test.

Hyperalgesia induced by inflammatory pain in DLC2 ${ }^{-/-}$mice may involve RhoA. A dramatic increase in RhoA activity was observed in the ipsilateral spinal cord $30 \mathrm{~min}$ after the formalin injection. It is well known that the activation of RhoA and its effector ROCK is related to spinal nociceptive transmission $[14,15,47,48]$ and that the inhibition of ROCK attenuates inflammatory and neuropathic pain $[13,47]$. In addition, a recent paper showed that the RhoA/ROCK pathway is also involved in thermal hyperalgesia in diabetic mice [49]. Furthermore, the activation of RhoA and ROCK is related to spinal no- ciceptive transmission $[14,15,47,48]$, and the inhibition of ROCK attenuates inflammatory and neuropathic pain $[13,47]$, whereas the activation of RhoA by the injection of lysophosphatidic acid induces hyperalgesia and allodynia [13]. The injection of H-1152, a ROCK inhibitor, significantly reduced the Phase II pain behavior resulting from the formalin injection by attenuating the phosphorylation of MARCKS in the superficial dorsal horn of the spinal cord [14]. Therefore, RhoA and ROCK are important regulators of inflammatory pain, and the de-regulation of RhoA may influence the inflammatory pain response.

The in vivo function of the DLC2 RhoGAP domain has not been fully determined, although this domain has been shown to have RhoGAP activity for RhoA and CDC42 in vitro [1]. However, the overexpression of DLC2 resulted in the inhibition of RhoA activity and in the reduction of actin stress fiber formation $[11,50]$, suggesting that DLC2 predominately regulates RhoA. Therefore, DLC2 is a negative regulator of RhoA activity, which may be involved in pain modulation.

\section{ERK1/2 Signaling May Affect DLC2-Induced Hyperalgesia}

ERK1/2 activation is involved in the inflammatory pain response but does not affect basal pain sensitivity [26]. Increased ERK1/2 activation was detected after complete Freund's adjuvant-induced inflammatory pain [26]. In addition, the inhibition of pERK1/2 attenuates inflammatory $[25,36,51]$, heat, and mechanical pain hypersensitivity [26]. In this study, we observed an increase in the number of pERK1/2-positive cells in the ipsilateral dorsal horn of the spinal cord (L4 and L5) of DLC2 $2^{-/}$ mice 5 min after a formalin injection, which is similar to a previous report [25]. The activity of ERK1/2 in both sides of the spinal cord was increased in $\mathrm{DLC}^{-/-}$mice compared to $\mathrm{DLC}_{2}{ }^{+/+}$mice.

In contrast to the immunocytochemical data, the quantitative Western blot analysis did not show an increase in pERK $1 / 2$ in the ipsilateral spinal cord compared to the contralateral side in $\mathrm{DLC}^{+/+}$mice 5 min after a formalin injection. Western blot analysis showed that pERK1/2 was increased in both the contralateral and ipsilateral sides of the spinal cord in DLC2 ${ }^{-/-}$mice compared to $\mathrm{DLC}^{+/+}$mice $5 \mathrm{~min}$ after a formalin injection. Nevertheless, an increase in pERK1/2 in the ipsilateral dorsal horn of the spinal cord in DLC2 $2^{-/-}$mice was observed $5 \mathrm{~min}$ after a formalin injection compared to $\mathrm{DLC}^{+/+}$mice. 


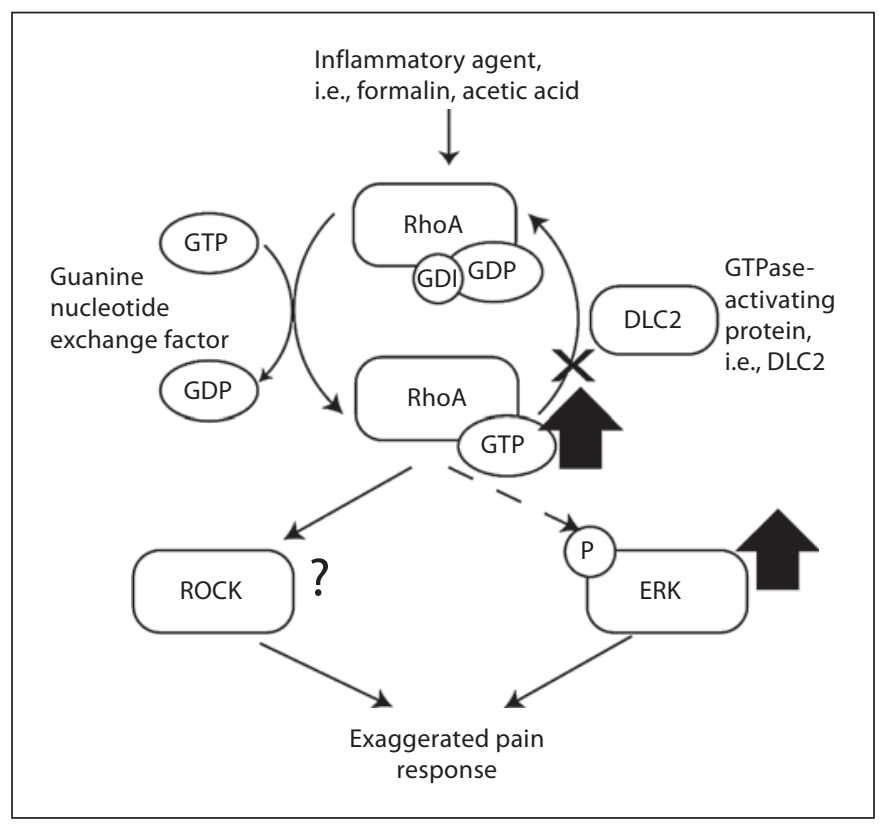

Fig. 6. Schematic diagram of the possible role of DLC2 and its downstream effectors. DLC2 is involved in the regulation of inflammatory pain perception via RhoA and its two possible downstream effectors ROCK and ERK. Dashed line indicates the effects between components, but the nature of their interaction remains to be investigated.

The activation of ERK1/2 peaks 5 min after stimulation and then decays 30-60 min after stimulation $[25,26$, 52]. It is not yet clear whether ERK1/2 activation occurs $5 \mathrm{~min}$ after a formalin injection, but the hyperalgesic effects were observed during Phase II, 20-30 min after the injection. Some studies suggest that ERK1/2 is involved in the central sensitization to acute noxious stimuli [26] and increased excitability of spinal neurons through the phosphorylation of the A-type potassium channel Kv4.2 [53]. In addition, ERK1/2 induces transcriptional changes in the spinal cord. pERK1/2 translocates to the nucleus and phosphorylates the transcription factor cAMP element-binding protein (CREB) and induces transcription via CREB kinase [54-56]. Moreover, the activation of ERK has been shown to induce NK-1, which plays an important role in inflammatory pain hypersensitivity [57, 58], and the expression of prodynorphin, which is involved in inflammation-induced enhanced excitability and expanded dorsal horn neuronal receptive fields [59, 60] after the induction of inflammatory pain [26]. Therefore, activation of ERK may contribute to acute inflammatory hyperalgesia through post-translational and -transcriptional regulation.
Recently, increasing evidence has suggested that RhoA regulates ERK1/2 signaling directly or through the regulation of MEK [61-63], although evidence for a direct link between RhoA and ERK1/2 activation in nervous tissues has not yet been determined. In this study, ERK1/2 activity in the ipsilateral spinal cord of DLC2 $2^{-/-}$mice peaked 5 min after the formalin injection, whereas RhoA in the ipsilateral spinal cord of DLC2 ${ }^{-/-}$mice was significantly activated $30 \mathrm{~min}$ after the injection, i.e. after Phase II. These data suggest that the induction of pERK1/2 in $\mathrm{DLC}^{-/-}$mice during inflammatory pain may be independent of RhoA activation. A recent study showed that DLC2 altered ERK1/2 activity and cell growth in HepG2 cells through the Raf1-ERK1/2-p70S6K pathway [27], suggesting that further investigation is necessary to reveal the underlying mechanism involving DLC2, RhoA, and ERK1/2 in pain perception.

Taken together, we have shown that DLC2 has RhoGAP activity for RhoA in nervous tissue. Loss of DLC2 led to the activation of RhoA and hyperalgesia after painful stimuli, such as formalin injection. Concomitantly, increased ERK1/2 phosphorylation was also observed in the ipsilateral side of the spinal cord of DLC2 ${ }^{-/-}$mice after injecting the animals with the inflammatory agent formalin (fig. 6). ERK activation also induced hypersensitivity to pain through the upregulation of various downstream effectors and an increase in neuronal excitability in the spinal cord [53]. Furthermore, ROCK activation downstream of RhoA may also contribute to hypersensitivity to pain by the phosphorylation of MARCKS and increased glutamate release. However, the precise mechanism involving DLC2, RhoA, and ERK1/2 has not yet been identified. Therefore, further investigation is necessary to determine the detailed mechanism of DLC2 involvement in inflammatory pain.

\section{Acknowledgements}

We thank Dr. T.O. Yau, Dr. Amy K.M. Lam and Mr. James Y.B. Lau for technical assistance in generating DLC2 $2^{-/-}$mice and Dr. Thomas H.Y. Leung for technical advice on Rhotekin binding assay. I.O. Ng is Loke Yew Professor in Pathology. This project is supported by CRCG funding, The University of Hong Kong, to S.K. Chung. 


\section{References}

$\checkmark 1$ Ching YP, Wong CM, Chan SF, Leung TH, $\mathrm{Ng}$ DC, Jin DY, Ng IO: Deleted in liver cancer (DLC) 2 encodes a RhoGAP protein with growth suppressor function and is underexpressed in hepatocellular carcinoma. J Biol Chem 2003;278:10824-10830.

$\checkmark 2$ Laurent-Puig P, Legoix P, Bluteau O, Belghiti J, Franco D, Binot F, Monges G, Thomas G, Bioulac-Sage P, Zucman-Rossi J: Genetic alterations associated with hepatocellular carcinomas define distinct pathways of hepatocarcinogenesis. Gastroenterology 2001;120: 1763-1773.

$\checkmark 3$ Piao Z, Park C, Park JH, Kim H: Allelotype analysis of hepatocellular carcinoma. Int J Cancer 1998;75:29-33.

4 Kuroki T, Fujiwara Y, Nakamori S, Imaoka S, Kanematsu T, Nakamura Y: Evidence for the presence of two tumour-suppressor genes for hepatocellular carcinoma on chromosome 13q. Br J Cancer 1995;72:383-385.

$\checkmark 5$ Nagai H, Pineau P, Tiollais P, Buendia MA, Dejean A: Comprehensive allelotyping of human hepatocellular carcinoma. Oncogene 1997;14:2927-2933.

6 Lin YW, Sheu JC, Huang GT, Lee HS, Chen CH, Wang JT, Lee PH, Lu FJ: Chromosomal abnormality in hepatocellular carcinoma by comparative genomic hybridisation in Taiwan. Eur J Cancer 1999;35:652-658.

$\checkmark 7$ Zondervan PE, Wink J, Alers JC, Ijzermans JN, Schalm SW, de Man RA, van Dekken H: Molecular cytogenetic evaluation of virusassociated and non-viral hepatocellular carcinoma: analysis of 26 carcinomas and 12 concurrent dysplasias. J Pathol 2000;192: 207-215.

$\checkmark 8$ Wong N, Lai P, Pang E, Leung TW, Lau JW, Johnson PJ: A comprehensive karyotypic study on human hepatocellular carcinoma by spectral karyotyping. Hepatology 2000; 32:1060-1068.

-9 Wang G, Zhao Y, Liu X, Wang L, Wu C, Zhang W, Liu W, Zhang P, Cong W, Zhu Y, Zhang L, Chen S, Wan D, Zhao X, Huang W, $\mathrm{Gu}$ J: Allelic loss and gain, but not genomic instability, as the major somatic mutation in primary hepatocellular carcinoma. Genes Chromosomes Cancer 2001;31:221-227.

$\checkmark 10$ Nagaraja GM, Kandpal RP: Chromosome 13 q12 encoded Rho GTPase activating protein suppresses growth of breast carcinoma cells, and yeast two-hybrid screen shows its interaction with several proteins. Biochem Biophys Res Commun 2004;313:654-665.

$>11$ Leung TH, Ching YP, Yam JW, Wong CM, Yau TO, Jin DY, Ng IO: Deleted in liver cancer 2 (DLC2) suppresses cell transformation by means of inhibition of RhoA activity. Proc Natl Acad Sci USA 2005;102:1520715212.
12 Yau TO, Leung THY, Lam SGS, Cheung OF Khong PL, Lam AKM, Chung SK, Ng IOL: Deleted in liver cancer 2 (DLC2) was dispensable for development and its deficiency did not aggravate hepatocarcinogenesis. PLoS One 2009;4:e6566.

13 Inoue M, Rashid MH, Fujita R, Contos JJ, Chun J, Ueda $\mathrm{H}$ : Initiation of neuropathic pain requires lysophosphatidic acid receptor signaling. Nat Med 2004;10:712-718.

14 Tatsumi S, Mabuchi T, Katano T, Matsumura S, Abe T, Hidaka H, Suzuki M, Sasaki Y, Minami T, Ito S: Involvement of Rho-kinase in inflammatory and neuropathic pain through phosphorylation of myristoylated alanine-rich C-kinase substrate (MARCKS). Neuroscience 2005;131:491-498.

15 Büyükafşa K, Yalçın I, Kurt AH, Tiftik RN, Sahan-Firat S, Aksu F: Rho-kinase inhibitor Y-27632, has an antinociceptive effect in mice. Eur J Pharmacol 2006;541:49-52.

16 Büyükafşa K, Levent A: Involvement of Rho/ Rho-kinase signalling in the contractile activity and acetylcholine release in the mouse gastric fundus. Biochem Biophys Res Commun 2003;303:777-781.

17 Sasaki Y: New aspects of neurotransmitter release and exocytosis: Rho-kinase-dependent myristoylated alanine-rich C-kinase substrate phosphorylation and regulation of neurofilament structure in neuronal cells. J Pharmacol Sci 2003;93:35-40.

18 McMullan R, Hiley E, Morrison P, Nurrish SJ: Rho is a presynaptic activator of neurotransmitter release at pre-existing synapses in C. elegans. Genes Dev 2006;20:65-76.

19 Crawley JN: What's Wrong with My Mouse? Behavioral Phenotyping of Transgenic and Knockout Mice. New York, Wiley-Liss, 2000.

20 Song Z, Fu DT, Chan YS, Leung S, Chung SS, Chung SK: Transgenic mice overexpressing aldose reductase in Schwann cells show more severe nerve conduction velocity deficit and oxidative stress under hyperglycemic stress. Mol Cell Neurosci 2003;23:638-647.

21 Ho EC, Lam KS, Chen YS, Yip JC, Arvindakshan M, Yamagishi S, Yagihashi S, Oates PJ, Ellery CA, Chung SS, Chung SK: Aldose reductase-deficient mice are protected from delayed motor nerve conduction velocity, increased c-Jun NH2-terminal kinase activation, depletion of reduced glutathione, increased superoxide accumulation, and DNA damage. Diabetes 2006;55:1946-1953.

22 De Koning P, Gispen WH: Org.2766 improves functional and electrophysiological aspects of regenerating sciatic nerve in the rat. Peptides 1987;8:415-422.

23 Chen YS, Chung SS, Chung SK: Noninvasive monitoring of diabetes-induced cutaneous nerve fiber loss and hypoalgesia in thy1-YFP transgenic mice. Diabetes 2005;54:31123118.
24 Lauria G, Cornblath DR, Johansson O, McArthur JC, Mellgren SI, Nolano M, Rosenberg N, Sommer C: EFNS guidelines on the use of skin biopsy in the diagnosis of peripheral neuropathy. Eur J Neurol 2005;12: 747-758.

25 Ji RR, Baba H, Brenner GJ, Woolf CJ: Nociceptive-specific activation of ERK in spinal neurons contributes to pain hypersensitivity. Nat Neurosci 1999;2:1114-1119.

26 Ji RR, Befort K, Brenner GJ, Woolf CJ: ERK MAP kinase activation in superficial spinal cord neurons induces prodynorphin and NK-1 upregulation and contributes to persistent inflammatory pain hypersensitivity. J Neurosci 2002;22:478-485.

$\checkmark 27$ Leung TH, Yam JW, Chan LK, Ching YP, Ng IO: Deleted in liver cancer 2 suppresses cell growth via the regulation of the Raf-1ERK1/2-p70S6K signalling pathway. Liver Int 2010;30:1315-1323.

$>28$ Tanaka H, Yoshida T, Miyamoto N, Motoike T, Kurosu H, Shibata K, Yamanaka A, Williams SC, Richardson JA, Tsujino N, Garry MG, Lerner MR, King DS, O’Dowd BF, Sakurai T, Yanagisawa M: Characterization of a family of endogenous neuropeptide ligands for the G protein-coupled receptors GPR7 and GPR8. Proc Natl Acad Sci USA 2003;100: 6251-6256

$>29$ Lee DK, Nguyen T, Porter CA, Cheng R, George SR, O'Dowd BF: Two related G protein-coupled receptors: the distribution of GPR7 in rat brain and the absence of GPR8 in rodents. Brain Res Mol Brain Res 1999;71: 96-103.

30 Neugebauer V, Li W, Bird GC, Han JS: The amygdala and persistent pain. Neuroscientist 2004;10:221-234.

-31 Khanna S, Chang LS, Jiang F, Koh HC: Nociception-driven decreased induction of Fos protein in ventral hippocampus field CA1 of the rat. Brain Res 2004;1004:167-176.

-32 Lanteri-Minet M, Isnardon P, de Pommery J, Menetrey D: Spinal and hindbrain structures involved in visceroception and visceronociception as revealed by the expression of Fos, Jun and Krox-24 proteins. Neuroscience 1993;55:737-753.

33 Mogil JS, Wilson SG, Bon K, Lee SE, Chung K, Raber P, Pieper JO, Hain HS, Belknap JK, Hubert L, Elmer GI, Chung JM, Devor M: Heritability of nociception II. 'Types' of nociception revealed by genetic correlation analysis. Pain 1999;80:83-93.

34 Kelly MA, Beuckmann CT, Williams SC, Sinton CM, Motoike T, Richardson JA, Hammer RE, Garry MG, Yanagisawa M: Neuropeptide B-deficient mice demonstrate hyperalgesia in response to inflammatory pain. Proc Natl Acad Sci USA 2005;102: 9942-9947. 
35 Gyires K, Torma Z: The use of the writhing test in mice for screening different types of analgesics. Arch Int Pharmacodyn Ther 1984;267:131-140.

-36 Karim F, Hu HJ, Adwanikar H, Kaplan D, Gereau RWt: Impaired inflammatory pain and thermal hyperalgesia in mice expressing neuron-specific dominant negative mitogen activated protein kinase kinase (MEK). Mol Pain 2006;2:2.

-37 Ramakers GJ: Rho proteins and the cellular mechanisms of mental retardation. Am J Med Genet 2000;94:367-371.

-38 Nakazawa T, Watabe AM, Tezuka T, Yoshida Y, Yokoyama K, Umemori H, Inoue A, Okabe S, Manabe T, Yamamoto T: p250GAP, a novel brain-enriched GTPase-activating protein for Rho family GTPases, is involved in the $\mathrm{N}$-methyl-d-aspartate receptor signaling. Mol Biol Cell 2003;14:2921-2934.

-39 Wong CM, Lee JM, Ching YP, Jin DY, Ng IO: Genetic and epigenetic alterations of DLC-1 gene in hepatocellular carcinoma. Cancer Res 2003;63:7646-7651.

40 Durkin ME, Avner MR, Huh CG, Yuan BZ, Thorgeirsson SS, Popescu NC: DLC-1, a Rho GTPase-activating protein with tumor suppressor function, is essential for embryonic development. FEBS Lett 2005;579:1191-1196.

41 Brouns MR, Matheson SF, Settleman J: p190 RhoGAP is the principal Src substrate in brain and regulates axon outgrowth, guidance and fasciculation. Nat Cell Biol 2001;3: 361-367.

-42 Soleimannejad E, Semnanian S, Fathollahi Y, Naghdi N: Microinjection of ritanserin into the dorsal hippocampal CA1 and dentate gyrus decrease nociceptive behavior in adult male rat. Behav Brain Res 2006;168: 221-225.

43 Masri R, Quiton RL, Lucas JM, Murray PD, Thompson SM, Keller A: Zona incerta: a role in central pain. J Neurophysiol 2009;102: 181-191.

44 Tucker KJ, Tuncer M, Türker KS: A review of the H-reflex and M-wave in the human triceps surae. Hum Mov Sci 2005;24:667688 .
45 Gally JA, Montague PR, Reeke GN Jr, Edelman GM: The NO hypothesis: possible effects of a short-lived, rapidly diffusible signal in the development and function of the nervous system. Proc Natl Acad Sci USA 1990; 87:3547-3551.

46 Matsumura S, Abe T, Mabuchi T, Katano T, Takagi K, Okuda-Ashitaka E, Tatsumi S, Nakai Y, Hidaka H, Suzuki M, Sasaki Y, Minami T, Ito S: Rho-kinase mediates spinal nitric oxide formation by prostaglandin E2 via EP3 subtype. Biochem Biophys Res Commun 2005;338:550-557.

47 Ye X, Inoue M, Ueda H: Botulinum toxin C3 inhibits hyperalgesia in mice with partial sciatic nerve injury. Jpn J Pharmacol 2000; 83:161-163.

48 Ohsawa M, Mutoh J, Hisa H: Mevalonate sensitizes the nociceptive transmission in the mouse spinal cord. Pain 2008;134:285292.

49 Ohsawa M, Aasato M, Hayashi SS, Kamei J: RhoA/Rho kinase pathway contributes to the pathogenesis of thermal hyperalgesia in diabetic mice. Pain 2011;152:114-122.

50 Kawai K, Kiyota M, Seike J, Deki Y, Yagisawa H: START-GAP3/DLC3 is a GAP for RhoA and Cdc42 and is localized in focal adhesions regulating cell morphology. Biochem Biophys Res Commun 2007;364:783-789.

51 Ji RR: Peripheral and central mechanisms of inflammatory pain, with emphasis on MAP kinases. Curr Drug Targets Inflamm Allergy 2004;3:299-303.

52 Sasagawa S, Ozaki Y, Fujita K, Kuroda S: Prediction and validation of the distinct dynamics of transient and sustained ERK activation. Nat Cell Biol 2005;7:365-373.

53 Morozov A, Muzzio IA, Bourtchouladze R, Van-Strien N, Lapidus K, Yin D, Winder DG, Adams JP, Sweatt JD, Kandel ER: Rap1 couples cAMP signaling to a distinct pool of p42/44MAPK regulating excitability, synaptic plasticity, learning, and memory. Neuron 2003;39:309-325.

54 Impey S, Obrietan K, Wong ST, Poser S, Yano S, Wayman G, Deloulme JC, Chan G, Storm DR: Cross talk between ERK and PKA is required for $\mathrm{Ca} 2+$ stimulation of CREB-dependent transcription and ERK nuclear translocation. Neuron 1998;21:869-883.
55 Obrietan K, Impey S, Smith D, Athos J, Storm DR: Circadian regulation of cAMP response element-mediated gene expression in the suprachiasmatic nuclei. J Biol Chem 1999;274:17748-17756.

56 Xing J, Ginty DD, Greenberg ME: Coupling of the RAS-MAPK pathway to gene activation by RSK2, a growth factor-regulated CREB kinase. Science 1996;273:959-963.

57 Abbadie C, Trafton J, Liu H, Mantyh PW, Basbaum AI: Inflammation increases the distribution of dorsal horn neurons that internalize the neurokinin-1 receptor in response to noxious and non-noxious stimulation. J Neurosci 1997;17:8049-8060.

58 McCarson KE, Krause JE: NK-1 and NK-3 type tachykinin receptor mRNA expression in the rat spinal cord dorsal horn is increased during adjuvant or formalin-induced nociception. J Neurosci 1994;14:712-720.

59 Dubner R, Ruda MA: Activity-dependent neuronal plasticity following tissue injury and inflammation. Trends Neurosci 1992; 15:96-103.

60 Hylden JL, Nahin RL, Traub RJ, Dubner R: Effects of spinal kappa-opioid receptor agonists on the responsiveness of nociceptive superficial dorsal horn neurons. Pain 1991;44: 187-193.

-61 Stahle M, Veit C, Bachfischer U, Schierling K, Skripczynski B, Hall A, Gierschik P, Giehl $\mathrm{K}$ : Mechanisms in LPA-induced tumor cell migration: critical role of phosphorylated ERK. J Cell Sci 2003;116:3835-3846.

62 Zhu S, Korzh V, Gong Z, Low BC: RhoA prevents apoptosis during zebrafish embryogenesis through activation of Mek/Erk pathway. Oncogene 2008;27:1580-1589.

63 Li H, Ung CY, Ma XH, Li BW, Low BC, Cao ZW, Chen YZ: Simulation of crosstalk between small GTPase RhoA and EGFR-ERK signaling pathway via MEKK1. Bioinformatics 2009;25:358-364. 